Research Article

\title{
Knowledge, Attitude, and Preventive Practices towards Sexually Transmitted Infections among Preparatory School Students in West Gojjam Zone, Ethiopia
}

\author{
Ayalnesh Asmamaw Kassie, ${ }^{1}$ Temesgen Worku Gudayu (iD, ${ }^{2}$ and Bilen Mekonnen Araya ${ }^{2}{ }^{2}$ \\ ${ }^{1}$ Ataye Primary Hospital, Amhara Regional Health Bureau, Bahir Dar, Ethiopia \\ ${ }^{2}$ Department of Clinical Midwifery, School of Midwifery, College of Medicine and Health Sciences, University of Gondar, \\ Gondar, Ethiopia
}

Correspondence should be addressed to Temesgen Worku Gudayu; teme.worku@gmail.com

Received 12 October 2019; Revised 3 March 2020; Accepted 20 March 2020; Published 12 May 2020

Academic Editor: Carol J. Burns

Copyright (c) 2020 Ayalnesh Asmamaw Kassie et al. This is an open access article distributed under the Creative Commons Attribution License, which permits unrestricted use, distribution, and reproduction in any medium, provided the original work is properly cited.

\begin{abstract}
Background. Sexually transmitted infections are major public health concerns that mostly affect adolescents and young people. Hence, the aim of this study was to assess students' knowledge, attitude, and preventive practice towards sexually transmitted infections and the associated factors. Methods. A school-based cross-sectional study was conducted from October 24 to November 4, 2018. A sample size of 845 was calculated and a 1-stage sampling technique was employed. Data were collected through a selfadministered questionnaire. The data were entered into Epi-Info 7.2 and analyzed using IBM SPSS version 25 software. The descriptive result was presented in text, figure, and tables. Also, bivariate and multivariable logistic regression analyses were done to identify associated factors. Then the adjusted odds ratio and its $95 \%$ confidence interval were computed. And a $p$ value of $<0.05$ was considered to assert statistical significance. Results. Half of the respondents (50.5\%) had good knowledge on sexually transmitted infections. Also, $46.4 \%$ of students had a good preventive practice. However, only $38.4 \%$ of students had an appropriate attitude towards sexually transmitted infections. Being a male (AOR: 1.58 (95\% CI: (1.19, 2.09)) and having employed father (AOR: 1.97 (95\% CI: $(1.18,3.30)$ ) predicted good knowledge. Similarly, secondary and above level of paternal education (AOR: 2.16 (95\% CI: $(1.28,3.64))$ and having a farmer father (AOR: 1.77 (95\% CI: $(1.04,3.02))$ predicted appropriate attitude. Predictors of preventive practices included elder age (AOR: 2.33 (95\% CI: $(1.27,4.28)$ ), never had sexual intercourse (AOR: 1.44 (95\% CI: $(1.07,1.94))$, and having good knowledge on STIs (AOR: 1.53 (95\% CI: $(1.16,2.02))$. Conclusion. The proportion of students that had good knowledge, appropriate attitude, and good preventive practice towards STIs were low. Personal and parental factors predicted students' knowledge, attitude, and preventive practices. Hence, creating awareness need to be strengthened.
\end{abstract}

\section{Background}

Sexually transmitted infections (STIs) are major universal public health concerns. The infections cause an acute illness, infertility, disability, and death [1]. Young people and adolescents are among the vulnerable groups for sexually transmitted infections (STIs). In a global report, there was an annual estimate of 357-376 million curable new cases of STIs that were diagnosed among adolescents and adults [2].
Adolescents, particularly students in developing countries, travel far away from their families and stay away for a long time when they attend secondary education. In their stay, they usually live in rented homes and come in contact with people from different sociocultural and behavioral background. Coupled with a lack of knowledge and available services about STIs, adolescents are more likely to practice unprotected sex and have multiple sexual partners and thereby have a higher chance of getting infected with STIs [3]. 
Most people in general and adolescents in particular might be aware of HIV/AIDs since the awareness created by media and government programs played a role. This, in turn, resulted in lower knowledge about STIs other than HIV/ AIDS and the knowledge could be much lower in developing countries [4]. In most cases, sexually transmitted infections are asymptomatic and that makes it difficult to diagnose [5]. In addition, most adolescents, those particularly from a rural society, might not have access to the required information and services to prevent STIs [3]. So, such a condition coupled with syndromic management of STIs in resourcelimited countries, could further facilitate the transmission of infection. As a result, particularly females who were infected with STIs could experience acute symptoms, chronic infection, and serious delayed consequences such as ectopic pregnancy, infertility, and cervical cancer [6].

Working on prevention is an ideal level to control STIs. Therefore, this study was aimed to assess knowledge, attitude, preventive practice, and associated factors towards sexually transmitted infections including HIV/AIDS among preparatory school students in West Gojjam zone.

\section{Methods}

2.1. Study Design. School-based cross-sectional study was employed among 845 preparatory school students.

2.2. Study Area and Period. The study was conducted in West Gojjam zone, Amhara region, Northwest Ethiopia from October 24 to November 4, 2018. West Gojjam zone is one of the administrative zones in Amhara regional state and based on a projected population of the 2007 Census [7], the Zone has a total population of 2,422,296 people, and 273,620 of them were urban inhabitants. West Gojjam zone had 13 woredas and 1 administrative town and a total of 14 preparatory schools found in the zone. Preparatory schools in the country provide education for two years at the level of $11^{\text {th }}$ and $12^{\text {th }}$ grade. The schools in the study area enrolled 22,728 students in the year 2018 in both $11^{\text {th }}$ and $12^{\text {th }}$ preparatory classes.

2.3. Population. The source population for this study was all regular preparatory school students in West Gojjam zone public schools who were registered at the academic year of 2018, whereas students who were attending their class at 4 of 14 randomly selected schools during the study period were study population.

2.4. Sample Size Determination. The sample size was determined by using single population proportion formula by considering 95\% confidence level, 5\% margin of error, and prevalence of respondents who had good knowledge on STIs from the previous study which was $50.83 \%$ [8], 10\% nonresponse rate, and the design effect of 2 . Then the final sample size of 845 was calculated.
2.5. Sampling Procedure. A one-stage random sampling technique was used to select four woredas (districts), namely, Finoteselam, Degadamot, Adet, and Gonij kolela, randomly with the assumption that all woredas in the zone are homogenous regarding knowledge of STI. Each selected district has 1 preparatory school and a total of 6576 students were enrolled in 2018 academic year in four selected districts. Then, the sample size was distributed to each school based on the number of students in $11^{\text {th }}$ and $12^{\text {th }}$ grades. Finally, we used students' list of each grade as a sampling frame, and a total of 845 students were selected by lottery method.

\subsection{Study Variables}

2.6.1. Dependent Variable. It is the level of students' knowledge, attitude, and preventive practices towards sexually transmitted infections.

\subsubsection{Independent Variable}

(1) Sociodemographic Factors. They include age, sex, religion, ethnics, living with a friend or with a parent, family's education, family's occupation status, family's income, and student's pocket money.

(2) Inducing Factors. They include peer pressure, drinking alcohol, watching porn movies, chat chewing, and sexual desire.

2.7. Data Collection Procedures. Data were collected using pretested and semistructured self-administered questionnaire. The questionnaire was developed in English by reviewing literature and then translated into local language Amharic and was retranslated back to English in order to check the consistency. The tool comprised of four parts: part one was a sociodemographic background of students and their parents, part two focused on the knowledge of students regarding STIs, part three focused on the attitude of the students towards STIs, and the fourth part was on the preventive practice of the students on STIs. Data collection was done by three diploma nursing professionals, and two BSc nurses supervised the data collection process.

2.8. Data Quality Control. The tool was evaluated by investigators and a pretest was conducted on $5 \%$ of the sample size among students in the schools not selected for the study. Based on pretest result, some modification was done on the tool. Moreover, one-day training was given for data collectors and supervisors on the objectives of the study, data collection methods, and the contents of the tool. Furthermore, the collected questionnaires were checked for completeness and on-spot corrective measures were taken both by data collectors and supervisors.

2.9. Data Processing and Analysis. The collected data were checked for completeness before the analysis. The data were 
entered in to Epi-Info version 7.2 and then exported to SPSS version 25 for analysis. Outcome variables were dichotomized and measured as follows:

Knowledge: for fifty items used to measure knowledge on the STIs, each right answer was given 1 and wrong or uncertain answer was scored 0 . Students who scored above the mean score for knowledge were considered as having a good knowledge regarding STIs [8].

Attitude: the 8 questions on the five-level Likert scale that had positive and negative responses were arranged from strongly disagree to strongly agree. Each question was then categorized as $0=$ strongly disagree, disagree, and neutral and $1=$ strongly agree and agree for statements requiring agreement. Whereas, "neutral" considered as agreement, the reverse category was used for statements requiring disagreement. Then, students who scored $50 \%$ and above were considered as having favorable/appropriate attitude towards STIs [9].

Preventive practice: students who answered above the mean score for 8 preventive practice questions were taken as having a good preventive practice [8].

Bivariate analysis was used to identify factors associated with outcome variables. Then multivariable logistic regression model was fitted to control the possible effect of confounders. Variables that had a $p$ value less than 0.2 in the bivariate analysis were fitted to multivariable logistic regression model. Then, adjusted odds ratio (AOR) and its 95\% confidence interval were reported, and a $p$ value $<0.05$ was used to determine statistically significant association.

\section{Results}

3.1. Sociodemographic Characteristics of the Respondents. A total of 828 out of 845 preparatory students completed and returned the questionnaire. The age of respondents ranged from 16 to 29 with a mean age of 20.0 years and standard deviation of 2.3. About 461 (55.7\%) respondents were male and the majority of the respondents, 701 $(84.7 \%)$, were orthodox Christians. Nearly two-thirds, 547 $(66.1 \%)$, of students were $11^{\text {th }}$ grade. Most of the students were living with their parents and, in more than two-thirds of cases, parents of students didn't attend formal education (Table 1).

3.2. Knowledge of Preparatory School Students about STIs. Of the total of 828 participants, $698(84.3 \%)$ had heard about STIs. The source of information was from school for 479 (68.7\%), from $\mathrm{TV} /$ radio for 276 (39.6\%), from friends for $105(15.1 \%)$, from families for $54(7.7 \%)$, and from other sources such as books and internet for $2(0.3 \%)$.

Concerning the causes of STIs, $350(42.3 \%)$ identified bacteria as a primary cause for STIs, 306 (37\%) virus, and $150(18.1 \%)$ fungus. However, bad hygiene of women or men, 127 (15.3\%), using unclean water, 93 (11.2\%), and sex during menstruation, 135 (16.3\%), were mentioned as a cause for STIs and 107 (12.9\%) didn't know the cause of STIs.
TABLE 1: Sociodemographic characteristics of preparatory school students in selected West Gojjam zone schools, Northwest Ethiopia, 2018.

\begin{tabular}{|c|c|c|}
\hline Variable & Frequency $(n=828)$ & Percent \\
\hline \multicolumn{3}{|l|}{ Age } \\
\hline $16-19$ & 374 & 45.1 \\
\hline $20-24$ & 402 & 48.6 \\
\hline $25-29$ & 52 & 6.3 \\
\hline \multicolumn{3}{|l|}{ Sex } \\
\hline Male & 461 & 55.7 \\
\hline Female & 367 & 44.3 \\
\hline \multicolumn{3}{|l|}{ Religion } \\
\hline Orthodox & 701 & 84.7 \\
\hline Muslim & 127 & 15.3 \\
\hline \multicolumn{3}{|l|}{ Grade } \\
\hline Grade 11 & 547 & 66.1 \\
\hline Grade 12 & 281 & 33.9 \\
\hline \multicolumn{3}{|l|}{ Marital status } \\
\hline Single & 719 & 86.8 \\
\hline Married & 109 & 13.2 \\
\hline \multicolumn{3}{|l|}{ Cohabitant } \\
\hline Family & 569 & 68.7 \\
\hline Friend in rental home & 160 & 19.3 \\
\hline Myself in rental home & 94 & 11.4 \\
\hline With my relatives & 5 & 0.6 \\
\hline \multicolumn{3}{|l|}{ Original resident } \\
\hline Rural & 514 & 62.1 \\
\hline Urban & 314 & 37.9 \\
\hline \multicolumn{3}{|l|}{ Educational level of mother } \\
\hline No formal education & 615 & 74.3 \\
\hline Primary $(1-8)$ & 88 & 10.6 \\
\hline Secondary (9-12) & 69 & 8.3 \\
\hline College and above & 56 & 6.8 \\
\hline \multicolumn{3}{|l|}{ Educational level of father } \\
\hline No formal education & 549 & 66.4 \\
\hline Primary $(1-8)$ & 117 & 14.1 \\
\hline Secondary $(9-12)$ & 64 & 7.7 \\
\hline College and above & 98 & 11.8 \\
\hline \multicolumn{3}{|l|}{ Mather's occupation } \\
\hline Farmer & 343 & 41.4 \\
\hline House wife & 288 & 34.8 \\
\hline Merchant & 106 & 12.8 \\
\hline Private org employee & 28 & 3.4 \\
\hline Government employee & 63 & 7.6 \\
\hline \multicolumn{3}{|l|}{ Father's occupation } \\
\hline Farmer & 443 & 53.5 \\
\hline Merchant & 215 & 26.0 \\
\hline Private org employee & 54 & 6.5 \\
\hline Government employee & 116 & 14.0 \\
\hline \multicolumn{3}{|c|}{ Earning monthly pocket money } \\
\hline Yes & 585 & 70.7 \\
\hline No & 343 & 29.3 \\
\hline
\end{tabular}

For the question asked to identify different types of STIs, $129(15.6 \%)$ of the respondents didn't know any types of STIs, whereas 55 (6.6\%) of respondents had mentioned TB as one of the causes of STIs.

Students were also asked to point out curable STIs. Accordingly, 422 (51\%) of them identified syphilis, 336 (40.6\%) gonorrhea, and $282(34.1 \%)$ candidiasis. On the contrary, 16 (1.9\%) participants replied erroneously HIV/ 
AIDS as curable STIs, while 159 (19.2\%) of respondents didn't know curable STIs.

More than three-quarters, 640 (77.3\%), of students mentioned sexual intercourse as a mode of transmission for STIs. Seven hundred sixteen $(86.5 \%)$ declared that STIs can be prevented and all of the respondents pointed out at least one possible preventive method. One hundred twenty-nine (15.6\%) of respondents didn't know the signs and symptoms of STIs, and 201 (24.6\%) also didn't know complications of STIs (Table 2).

3.3. Attitude of Preparatory School Students towards STIs. In an attitude response, 496 (60\%) students disagreed on the vulnerability of adolescents for STIs. On the other hand, about $45 \%$ of students agreed on the presence of curable and noncurable STIs. Six hundred twenty-seven (75.7\%) of respondents also agreed on the idea "person infected with STIs can go to health institution for treatment," whereas 446 (54\%) disagreed on the concept "by treating an individual who had STIs, spread of the disease can be prevented" (Table 3).

3.4. Preventive Practice of Preparatory School Students on STIs. From the total of 828 participants, 277 (33.5\%) had a history of sexual intercourse in the period of the last six months. Thirty-six (12.9\%) of those who had sex had sex with their teachers and $9(3.2 \%)$ had sex with commercial sex workers.

More than half of the students were practicing abstinence and faithfulness as a means of preventive practice. Nearly one-tenth of the students practiced washing genitalia before and after sexual intercourse as a preventive measure for STIs (Table 4).

3.5. Proportion of Knowledge, Attitude, and Preventive Practice of STIs. This study revealed that 50.5\% (95\% CI: $(47.1 \%-53.9 \%))$ of students had a good knowledge of STIs. The proportion of appropriate attitude towards STIs among preparatory school students was 38.4\% (95\% CI: (34.9\%$41.7 \%)$ ). Less than half, $46.4 \%$ (95\% CI: $(43.0 \%-50.0 \%)$ ), of the students in this study also had a good preventive practice for STIs (Figure 1).

3.6. Factors Associated with Knowledge, Attitude, and Preventive Practice of Students towards STIs. The results of multivariable logistic regression analysis showed that sex of students and fathers' occupation were significantly associated with students' knowledge of STIs. Accordingly, male students were more likely to have good knowledge (AOR: 1.58 (95\% CI: $(1.19,2.09))$ than female students. Likewise, students whose fathers were employed were also more likely to have good knowledge (AOR: 1.97 (95\% CI: (1.18, 3.30)) than farmers.

Regarding the attitude of students, fathers' level of education and occupation found to predict the attitude of students towards STIs. Consequently, students of fathers who attended secondary and above level education (AOR: 2.16 (95\% CI: $(1.28,3.64))$ and whose occupation was farmer (AOR: 1.77 (95\% CI: $(1.04,3.02))$ had the appropriate attitude towards STIs.
In this study, the preventive practice of STIs among students was predicted by students' age, history of ever practice of sexual intercourse, and knowledge of students on STIs. Students aged 25-29 years had more than two times the odds of good preventive practice (AOR: 2.33 (95\% CI: $(1.27,4.28))$. Similarly, those students who never practiced sexual intercourse had good preventive practice for STIs (AOR: 1.44 (95\% CI: $(1.07,1.94)$ ). Likewise, students who had good knowledge of STIs were more likely to have good preventive practice (AOR: 1.53 (95\% CI: (1.16, 2.02)) (Table 5).

\section{Discussion}

This study revealed that about half of the students had a good knowledge of STIs. And $46 \%$ of students had a good preventive practice for STIs. However, only about 38\% of students had an appropriate attitude towards STIs.

The proportion of students who had good knowledge about STIs in this study is comparable with a study conducted at Arsi Negelle; the use of equivalent items to measure knowledge and similar categorization could be an explanation for the similarity [8]. A different classification with fewer items which has shown a wide variation in proportion could farther support this elucidation [10]. Concerning attitude, the Jimma town study [9] showed a higher proportion of appropriate attitude among students than the current study. Though similar categorization was used to measure attitude, students from a single urban school could have a better understanding of each item. The higher proportion of preventive practice of STIs among students in the current study with that of Arsi Negelle study [8] which used related measurement and items could be attributed to using all students in our case versus those who are sexually active in their study.

Male students are more likely to have a good level of knowledge than females in this study. This finding is in line with the finding from Arsi Negelle town study [8], in which males were nearly two times more likely to have good knowledge about STIs than females. Males in Ethiopian society in most cases spend much of their time outdoor than females. This could increase the exposure of males to different information including STIs. Likewise, the association of father's occupation as an employee with STIs knowledge among students in this study might play a key role in students' level of knowledge as employed parents could have better exposure to information.

In the current study, those students whose fathers had attended secondary and above level of education had two times more likely odds of having an appropriate attitude towards STIs. As reported in some studies, parental education [11] found to increase adolescent-parent communication on reproductive health issues and such communication also keeps them from risky sexual behavior [12]. Similarly, students whose fathers are farmers were about two times more likely to have an appropriate attitude towards STIs than those having employed fathers. A study [12] identified that authoritarian parenting style and parental monitoring found to protect from risky sexual 
TABLE 2: Knowledge on the mode of transmission, prevention methods, signs, and symptoms and complication of STIs among preparatory school students in West Gojjam zone, Northwest Ethiopia, 2018.

\begin{tabular}{|c|c|c|}
\hline Variable $(n=828)$ & Frequency & Percent \\
\hline \multicolumn{3}{|c|}{ Modes of transmission of STIs (multiple responses possible) } \\
\hline Sexual intercourse & 640 & 77.3 \\
\hline Sharing needle & 259 & 31.3 \\
\hline Blood transfusion & 163 & 19.7 \\
\hline Sharing clothes & 74 & 8.4 \\
\hline Mosquito bits & 68 & 8.2 \\
\hline Kissing & 252 & 30.2 \\
\hline \multicolumn{3}{|l|}{ STIs are preventable } \\
\hline Yes & 716 & 86.5 \\
\hline No & 112 & 13.5 \\
\hline \multicolumn{3}{|c|}{ Prevention methods of STIs (multiple responses possible) } \\
\hline Abstinence & 435 & 63.7 \\
\hline Condom & 256 & 37.5 \\
\hline Not having multiple sexual partners & 118 & 17.3 \\
\hline \multicolumn{3}{|c|}{ Signs and symptoms of STIs (multiple responses possible) } \\
\hline Lower abdominal pain & 165 & 19.9 \\
\hline Discharge from penis and vulva & 278 & 33.6 \\
\hline Itching on the genital area & 319 & 38.5 \\
\hline Failure to urinate & 218 & 26.3 \\
\hline Loss of weight & 169 & 20.4 \\
\hline Weakness & 139 & 16.8 \\
\hline Pain during intercourse & 191 & 23.1 \\
\hline Genital ulcers or open sores & 269 & 32.5 \\
\hline Don’t know & 129 & 15.6 \\
\hline \multicolumn{3}{|c|}{ Complications of STIs, if untreated (multiple responses possible) } \\
\hline Infertility & 311 & 37.6 \\
\hline Premature birth & 199 & 24.0 \\
\hline Stillbirth & 201 & 24.3 \\
\hline Ectopic pregnancy & 155 & 18.7 \\
\hline Miscarriage & 180 & 21.7 \\
\hline Cervical cancer & 261 & 31.5 \\
\hline Don't know & 201 & 24.6 \\
\hline
\end{tabular}

TABLE 3: Attitudes of preparatory school students towards STIs, West Gojjam zone, Northwest Ethiopia, 2018.

\begin{tabular}{|c|c|c|c|c|c|}
\hline \multirow[b]{2}{*}{ STIs attitude items } & \multicolumn{5}{|c|}{ Scale } \\
\hline & $\begin{array}{l}\text { Strongly } \\
\text { disagree }\end{array}$ & Disagree & Neutral & Agree & $\begin{array}{c}\text { Strongly } \\
\text { agree }\end{array}$ \\
\hline Adolescents are more vulnerable to STIs & $99(12.0 \%)$ & $\begin{array}{c}134 \\
(16.1 \%)\end{array}$ & $85(10.3 \%)$ & $\begin{array}{c}247 \\
(29.8 \%)\end{array}$ & $263(31.8 \%)$ \\
\hline STIs can cause social stigma and discrimination & $144(17.4 \%)$ & $\begin{array}{c}237 \\
(28.6 \%)\end{array}$ & $\begin{array}{c}129 \\
(15.6 \%)\end{array}$ & $\begin{array}{c}179 \\
(21.6 \%)\end{array}$ & $139(16.8 \%)$ \\
\hline Patients with STIs are easily identified in the community & $189(22.8 \%)$ & $\begin{array}{c}277 \\
(33.5 \%)\end{array}$ & $\begin{array}{c}131 \\
(15.8 \%)\end{array}$ & $\begin{array}{c}156 \\
(18.8 \%)\end{array}$ & $75(9.1 \%)$ \\
\hline There are both curable and noncurable STIs & $89(10.7 \%)$ & $\begin{array}{c}180 \\
(21.7 \%)\end{array}$ & $\begin{array}{c}182 \\
(22.0 \%)\end{array}$ & $\begin{array}{c}267 \\
(32.3 \%)\end{array}$ & $110(13.3 \%)$ \\
\hline Anybody can get condom simply when the need arises & $111(13.4 \%)$ & $\begin{array}{c}169 \\
(20.4 \%)\end{array}$ & $\begin{array}{c}175 \\
(21.1 \%)\end{array}$ & $\begin{array}{c}207 \\
(25.1 \%)\end{array}$ & $166(20.0 \%)$ \\
\hline Person infected with STIs can go to health institution for treatment & $30(3.6 \%)$ & $65(7.9 \%)$ & $\begin{array}{c}106 \\
(12.8 \%)\end{array}$ & $\begin{array}{c}327 \\
(39.5 \%)\end{array}$ & $300(36.2 \%)$ \\
\hline $\begin{array}{l}\text { By treating an individual who has STIs, spread of the disease can be } \\
\text { prevented }\end{array}$ & $232(28.0 \%)$ & $\begin{array}{c}214 \\
(26.0 \%)\end{array}$ & $\begin{array}{c}110 \\
(13.3 \%)\end{array}$ & $\begin{array}{c}197 \\
(23.6 \%)\end{array}$ & $76(9.1 \%)$ \\
\hline $\begin{array}{l}\text { Being infected with one of STIs other than HIV can increase the risk } \\
\text { of acquisition of HIV }\end{array}$ & $179(21.6 \%)$ & $\begin{array}{c}190 \\
(23.0 \%)\end{array}$ & $\begin{array}{c}101 \\
(12.0 \%)\end{array}$ & $\begin{array}{c}171 \\
(20.6 \%)\end{array}$ & $187(22.8 \%)$ \\
\hline
\end{tabular}

behavior. This nature could be more practiced by rural families mostly among farmers, so that children might be more normative.
Students who had good knowledge of STIs in this study were more likely to have good preventive practice for STIs. This finding is also supported by a study done in Arsi 
TABLE 4: Sexual practice and prevention practices for STIs among preparatory school students, West Gojjam zone, Northwest Ethiopia, 2018.

\begin{tabular}{lc}
\hline STIs preventive practice items & Frequency $(n=828)$ \\
\hline Have you had sexual intercourse in the last six months? & 551 \\
No & 277 \\
Yes & 551 \\
If yes, whom with did you had sexual intercourse? & 140 \\
Had no sexual intercourse at all & 89 \\
With my boy/girlfriend & 36 \\
With my classmate & 9 \\
With my teacher & 33.5 \\
With commercial sex workers & 66.5 \\
Wives/husbands & 16.9 \\
What measures did you take to prevent yourself from STIs ever? (multiple responses possible) & 10.7 \\
Abstinence & 4.3 \\
Being faithful & 1.1 \\
Use condom & 0.5 \\
Avoid sex with commercial sex workers & 461 \\
Wash genitalia before sex & 422 \\
Wash genitalia after sex & 198 \\
Decrease number of sexual partners & 96 \\
Not receiving unscreened blood & 745 \\
& 55.7 \\
& 51.0 \\
& 23.9 \\
& 11.6 \\
& 90.0 \\
& 91.9 \\
& 56.0 \\
\end{tabular}

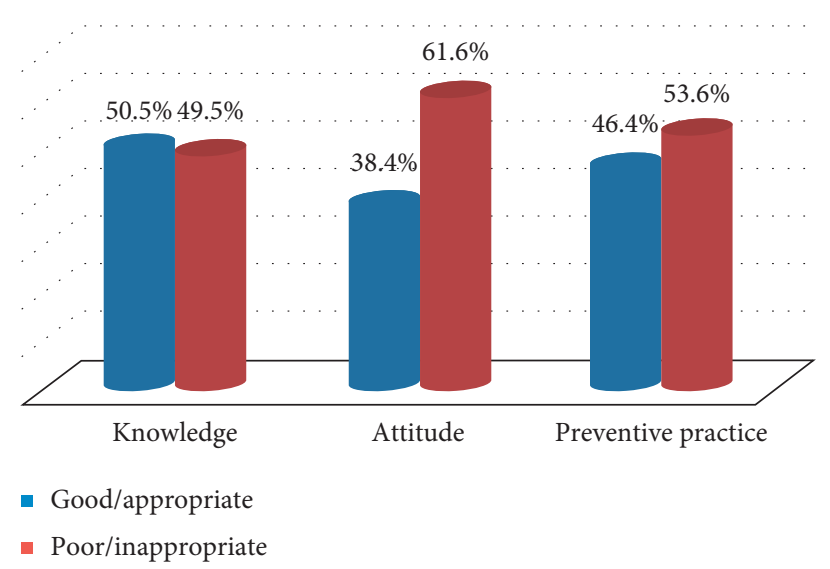

Figure 1: Proportion of knowledge, attitude, and preventive practice of preparatory school students on STIs, West Gojjam zone, Northwest Ethiopia, 2018.

TABLE 5: Factors associated with knowledge, attitude, and preventive practice on STIs among preparatory school students, West Gojjam zone, Northwest Ethiopia, 2018.

\begin{tabular}{|c|c|c|c|c|c|c|c|c|}
\hline \multirow[b]{2}{*}{ Variable } & \multicolumn{2}{|c|}{ Knowledge } & \multirow[b]{2}{*}{$\begin{array}{c}\text { AOR }(95 \% \\
\text { CI })\end{array}$} & Attitude & \multirow[b]{2}{*}{$\begin{array}{c}\text { AOR }(95 \% \\
\text { CI })\end{array}$} & \multicolumn{2}{|c|}{ Practice } & \multirow[b]{2}{*}{$\begin{array}{c}\text { AOR }(95 \% \\
\text { CI) }\end{array}$} \\
\hline & $\begin{array}{c}\text { Good } \\
(\%)\end{array}$ & Poor (\%) & & Appropriate Inappropriate & & $\begin{array}{l}\text { Good } \\
(\%)\end{array}$ & Poor (\%) & \\
\hline \multicolumn{9}{|l|}{ Age of students } \\
\hline $15-19$ years & & & & & & $\begin{array}{c}160 \\
(42.8)\end{array}$ & $\begin{array}{c}214 \\
(57.2)\end{array}$ & 1 \\
\hline $20-24$ years & & & & & & $193(48)$ & $\begin{array}{c}209 \\
(52.0)\end{array}$ & $\begin{array}{c}1.29(0.96 \\
1.72)\end{array}$ \\
\hline 25-29 years & & & & & & $16(69.6)$ & $7(30.4)$ & $\begin{array}{c}2.33(1.27 \\
4.28)\end{array}$ \\
\hline Sex of the students & & & & & & & & NA \\
\hline Male & $\begin{array}{c}254 \\
(55.1)\end{array}$ & $\begin{array}{c}207 \\
(44.9)\end{array}$ & $\begin{array}{c}1.58(1.19 \\
2.09)\end{array}$ & & & $\begin{array}{c}222 \\
(48.2)\end{array}$ & $\begin{array}{c}239 \\
(51.8)\end{array}$ & \\
\hline Female & $\begin{array}{c}164 \\
(44.7)\end{array}$ & $\begin{array}{c}203 \\
(55.3)\end{array}$ & 1 & & & $\begin{array}{c}162 \\
(44.1)\end{array}$ & $\begin{array}{c}205 \\
(55.9)\end{array}$ & \\
\hline Religion of students & & & NA & & & & & NA \\
\hline Orthodox christianity & $\begin{array}{c}346 \\
(49.4)\end{array}$ & $\begin{array}{c}355 \\
(50.6)\end{array}$ & & & & $\begin{array}{c}303 \\
(43.2)\end{array}$ & $\begin{array}{c}398 \\
(56.8)\end{array}$ & \\
\hline
\end{tabular}


TABLE 5: Continued.

\begin{tabular}{|c|c|c|c|c|c|c|c|c|c|}
\hline \multirow[b]{2}{*}{ Variable } & \multicolumn{2}{|c|}{ Knowledge } & \multirow{2}{*}{$\begin{array}{l}\mathrm{AOR}(95 \% \\
\mathrm{CI})\end{array}$} & \multicolumn{2}{|c|}{ Attitude } & \multirow{2}{*}{$\begin{array}{l}\text { AOR }(95 \% \\
\text { CI })\end{array}$} & \multicolumn{2}{|c|}{ Practice } & \multirow{2}{*}{$\begin{array}{l}\text { AOR }(95 \% \\
\text { CI })\end{array}$} \\
\hline & $\begin{array}{l}\text { Good } \\
(\%)\end{array}$ & Poor $(\%)$ & & Appropriate & Inappropriate & & $\begin{array}{l}\text { Good } \\
(\%)\end{array}$ & Poor $(\%)$ & \\
\hline Muslim & $72(56.7)$ & $55(43.3)$ & & & & & $81(63.8)$ & $46(36.2)$ & \\
\hline Grade of students & & & & & & & & & NA \\
\hline $11^{\text {th }}$ grade & & & & & & & $\begin{array}{c}262 \\
(47.9)\end{array}$ & $\begin{array}{c}285 \\
(52.1)\end{array}$ & \\
\hline $12^{\text {th }}$ grade & & & & & & & $\begin{array}{c}122 \\
(43.4)\end{array}$ & $\begin{array}{c}159 \\
(56.6)\end{array}$ & \\
\hline Cohabitant & & & & & & NA & & & NA \\
\hline With my parents or relatives & & & & $211(36.8)$ & $363(63.2)$ & & $\begin{array}{c}255 \\
(44.4)\end{array}$ & $\begin{array}{c}319 \\
(55.6)\end{array}$ & \\
\hline With my friend in rental home & & & & $62(38.8)$ & $98(61.2)$ & & $88(55.0)$ & $72(45.0)$ & \\
\hline Myself in rental home & & & & $45(47.9)$ & $49(52.1)$ & & $41(43.6)$ & $53(56.4)$ & \\
\hline Original residence & & & NA & & & & & & NA \\
\hline Rural & $\begin{array}{c}250 \\
(48.6)\end{array}$ & $\begin{array}{c}264 \\
(51.4)\end{array}$ & & & & & $\begin{array}{c}227 \\
(44.2)\end{array}$ & $\begin{array}{c}287 \\
(55.8)\end{array}$ & \\
\hline Urban & $\begin{array}{c}168 \\
(53.5)\end{array}$ & $\begin{array}{c}146 \\
(46.5)\end{array}$ & & & & & $\begin{array}{c}157 \\
(50.0)\end{array}$ & $\begin{array}{c}157 \\
(50.0)\end{array}$ & \\
\hline Mother's level of education & & & NA & & & & & & NA \\
\hline No formal education & $\begin{array}{c}302 \\
(49.1)\end{array}$ & $\begin{array}{c}313 \\
(50.9)\end{array}$ & & & & & $\begin{array}{c}280 \\
(45.5)\end{array}$ & $\begin{array}{c}335 \\
(54.5)\end{array}$ & \\
\hline $\begin{array}{l}\text { Primary level of education } \\
\left(1^{\text {st }}-8^{\text {th }} \text { grade }\right)\end{array}$ & $50(56.8)$ & $38(43.2)$ & & & & & $44(50.0)$ & $44(50.0)$ & \\
\hline Secondary and above & $66(52.8)$ & $59(47.2)$ & & & & & $60(48.0)$ & $65(52.0)$ & \\
\hline Father's level of education & & & NA & & & & & & NA \\
\hline No formal education & $\begin{array}{c}275 \\
(50.1)\end{array}$ & $\begin{array}{c}274 \\
(49.9)\end{array}$ & & $202(36.8)$ & $347(63.2)$ & 1 & $247(45)$ & $\begin{array}{c}302 \\
(55.0)\end{array}$ & \\
\hline $\begin{array}{l}\text { Primary level of education } \\
\left(1^{\text {st }}-8^{\text {th }} \text { grade }\right)\end{array}$ & $51(43.6)$ & $66(56.4)$ & & $42(35.9)$ & $75(64.1)$ & $\begin{array}{l}1.18(1.04 \\
3.02)\end{array}$ & $58(49.6)$ & $59(50.4)$ & \\
\hline Secondary and above & $92(56.8)$ & $70(43.2)$ & & $74(45.7)$ & $88(54.3)$ & $\begin{array}{l}2.16(1.28 \\
3.64)\end{array}$ & $79(48.8)$ & $83(51.2)$ & \\
\hline Mother's occupation & & & NA & & & & & & NA \\
\hline House wife & $\begin{array}{c}163 \\
(47.5)\end{array}$ & $\begin{array}{c}180 \\
(52.5)\end{array}$ & & & & & $\begin{array}{c}155 \\
(45.2)\end{array}$ & $\begin{array}{c}188 \\
(54.8)\end{array}$ & \\
\hline Farmer & $\begin{array}{c}143 \\
(49.7)\end{array}$ & $\begin{array}{c}145 \\
(50.3)\end{array}$ & & & & & $\begin{array}{c}127 \\
(44.1)\end{array}$ & $\begin{array}{c}161 \\
(55.9)\end{array}$ & \\
\hline Merchant & $57(53.8)$ & $49(46.2)$ & & & & & $57(53.8)$ & $49(46.2)$ & \\
\hline Employee & $55(60.4)$ & $36(39.6)$ & & & & & $45(49.5)$ & $46(50.5)$ & \\
\hline Father's occupation & & & & & & & & & NA \\
\hline Farmer & $\begin{array}{c}207 \\
(46.7)\end{array}$ & $\begin{array}{c}236 \\
(53.3)\end{array}$ & 1 & $178(40.2)$ & $265(59.8)$ & $\begin{array}{c}1.77(1.04 \\
3.02)\end{array}$ & $\begin{array}{c}193 \\
(43.6)\end{array}$ & $\begin{array}{c}250 \\
(56.4)\end{array}$ & \\
\hline Merchant & $\begin{array}{c}111 \\
(51.6)\end{array}$ & $\begin{array}{c}104 \\
(48.4)\end{array}$ & $\begin{array}{l}1.35(0.95 \\
1.93)\end{array}$ & $72(33.5)$ & $143(66.5)$ & $\begin{array}{c}1.14(0.69 \\
1.89)\end{array}$ & $\begin{array}{c}107 \\
(49.8)\end{array}$ & $\begin{array}{c}108 \\
(50.2)\end{array}$ & \\
\hline Employee & $\begin{array}{c}100 \\
(58.8)\end{array}$ & $70(41.2)$ & $\begin{array}{l}1.97(1.18 \\
3.30)\end{array}$ & $68(40.0)$ & $102(60.0)$ & 1 & $84(49.4)$ & $86(50.6)$ & \\
\hline \multicolumn{10}{|l|}{ Ever practiced sexual intercourse } \\
\hline No & & & & & & & $\begin{array}{c}268 \\
(48.6)\end{array}$ & $\begin{array}{c}283 \\
(51.4)\end{array}$ & $\begin{array}{l}1.44(1.07 \\
1.94)\end{array}$ \\
\hline Yes & & & & & & & $\begin{array}{c}116 \\
(41.9)\end{array}$ & $\begin{array}{c}161 \\
(58.1)\end{array}$ & 1 \\
\hline Earning monthly pocket money & & & & & & & & & NA \\
\hline No & & & & & & & $\begin{array}{c}116 \\
(47.7)\end{array}$ & $\begin{array}{c}127 \\
(52.3)\end{array}$ & \\
\hline Yes & & & & & & & $\begin{array}{c}268 \\
(45.8)\end{array}$ & $\begin{array}{c}317 \\
(54.2)\end{array}$ & \\
\hline \multicolumn{10}{|l|}{ Knowledge on STIs } \\
\hline Poor & & & & & & & $\begin{array}{c}169 \\
(41.2)\end{array}$ & $\begin{array}{c}241 \\
(58.8)\end{array}$ & 1 \\
\hline Good & & & & & & & $\begin{array}{c}215 \\
(51.4)\end{array}$ & $\begin{array}{c}203 \\
(48.6)\end{array}$ & $\begin{array}{c}1.53(1.16 \\
2.02)\end{array}$ \\
\hline
\end{tabular}

Negelle [8]. Also, older students were more likely to have good preventive practice than younger students. As revealed in a study [13], being older student had a significant association with good knowledge which could reflect that the more advanced the age, the better the knowledge, and thereby the better the preventive practice. Further, good practice among students who never had sexual intercourse could be attributed to the higher proportion of abstinence in the current study as a component of preventive practice. 
This study determined the proportion of knowledge, preventive practice, and attitude of students towards STIs. Further, the study identified some important factors that predicted students' knowledge, attitude, and preventive practice. However, some behavioral and sociocultural factors that had not been addressed here could seek a qualitative design.

\section{Conclusion}

The proportion of respondents that had good knowledge, appropriate attitude, and preventive practice of STIs among preparatory school students in this study were not satisfactory. Personal sociodemographic as well as behavioral and parental factors predicted students' knowledge, attitude, and preventive practices. Since youthhood, particularly at the end of preuniversity school, is a critical age, it is imperative to reinforce strategies which would improve adolescents' knowledge, attitude, and preventive practice towards STIs.

\section{Abbreviations}

AOR: Adjusted odds ratio

STIs: Sexually transmitted infections

TB: Tuberculosis

\section{Data Availability}

The datasets used and/or analyzed during the current study are available from the corresponding author on reasonable request.

\section{Ethical Approval}

Ethical clearance was obtained from the ethical committee of the School of Midwifery, College of Medicine and Health Sciences, University of Gondar. The committee is a delegate of the institutional review board of the university to provide ethical clearance for observational studies to masters and below level of students. After getting ethical clearance, support letter was written to West Gojjam zone educational office and the zone then wrote a support letter to selected preparatory schools.

\section{Consent}

In case students under the age of 16 years are selected in the study, a written informed consent form was prepared to obtain approval from their parent or guardian. All study participants were clearly informed about the purpose of the study and, along with self-administered questionnaire, a written consent was attached to be signed if they agree to participate. Then students were assured that all data they offer will be confidential and none of the personal identifiers are part of the data. Students were also guaranteed that they have the right to not to respond to the questions they are not interested in and that they have the right to withdraw at any point from the study.

\section{Conflicts of Interest}

The authors declare that they have no conflicts of interest.

\section{Authors' Contributions}

AAK conceived and designed the idea, participated in data management, analysis, interpretation, and paper write-up. TWG and BMA participated in design, data analysis, and interpretation. Finally, all authors developed and approved the manuscript.

\section{Acknowledgments}

The authors would like to express their gratitude to data collectors and supervisors for their commitment. The authors would also like to extend their appreciation to officials of the zonal educational office, directors and teachers of each school, and study participants. Data collection fee was covered by the Amhara Regional Health Bureau.

\section{References}

[1] WHO, Global Incidence and Prevalence of Selected Curable Sexually Transmitted Infections-2008, World Health Organization, Geneva, Switzerland, 2012.

[2] WHO, Global Health Sector Strategy on Sexually Transmitted Infections 2016-2021: Toward Ending STIs, World Health Organization, Geneva, Switzerland, 2016.

[3] E. C. Tilson, V. Sanchez, C. L. Ford et al., "Barriers to asymptomatic screening and other STD services for adolescents and young adults: focus group discussions," BMC Public Health, vol. 4, no. 1, p. 21, 2004.

[4] M. Anwar, S. A. S. Sulaiman, K. Ahmadi, and T. M. Khan, "Awareness of school students on sexually transmitted infections (STIs) and their sexual behavior: a cross-sectional study conducted in Pulau Pinang, Malaysia," BMC Public Health, vol. 10, no. 1, p. 47, 2010.

[5] A. Kaida, J. J. Dietrich, F. Laher et al., "A high burden of asymptomatic genital tract infections undermines the syndromic management approach among adolescents and young adults in South Africa: implications for HIV prevention efforts," BMC Infectious Diseases, vol. 18, no. 1, p. 499, 2018.

[6] S. Bernstein and C. J. Hansen, Public Choices, Private Decisions: Sexual and Reproductive Health and the Millennium Development Goals. Public Choices, Private Decisions: Sexual and Reproductive Health and the Millennium Development Goals, World Health Organization, New York, NY, USA, 2006.

[7] Federal Democratic Republic of Ethiopia Central Statistical Agency, Population Projection of Ethiopia for all Regions at Wereda Level from 2014-2017, Federal Democratic Republic of Ethiopia Central Statistical Agency, Addis Ababa, Ethiopia, 2013.

[8] N. D. Megersa, S. M. Ahmed, B. T. Gutema, G. S. Teshome, Z. A. Melketsedik, and E. Z. Tariku, "Knowledge, attitude and preventive practices towards sexually transmitted infection among preparatory school students of Arsi Negelle town," Journal of AIDS and Clinical Research, vol. 8, no. 12, 2017.

[9] A. Demis, A. Adera, and D. Workeneh, "Determination of knowledge, attitudes and practices on prevention of sexually transmitted infections among seto semero high school students," MOJ Public Health, vol. 5, no. 5, pp. 142-153, 2017. 
[10] G. Kejela and B. Saboka, "Assessment of knowledge, attitude and preventive practices towards sexually transmitted infections among preparatory school students in shone town, Southern Ethiopia, 2014," Journal of Health and Medical Information, vol. 6, no. 1, p. 183, 2015.

[11] Z. Yowhanes, H. Berhe, and D. Hailu, "Assessment of parentadolescent communication about sexual and reproductive health among high school students in mekelle town, Northern Ethiopia," Global Journal of Medical Research, vol. 16, no. 2-E, 2016.

[12] A. Cherie and Y. Berhanie, "Assessment of parenting practices and styles and adolescent sexual behavior among high school adolescents in Addis Ababa, Ethiopia," Journal of AIDS and Clinical Research, vol. 6, no. 2, p. 424, 2015.

[13] A. Folasayo, A. Oluwasegun, S. Samsudin, S. Saudi, M. Osman, and R. Hamat, "Assessing the knowledge level, attitudes, risky behaviors and preventive practices on sexually transmitted diseases among university students as future healthcare providers in the central zone of Malaysia: a crosssectional study," International Journal of Environmental Research and Public Health, vol. 14, no. 2, p. 159, 2017. 